\title{
Which Agroforestry Practice Is Beneficial? A Comparative Assessment of the Traditional and the Improved Agroforestry Techniques in the Midhills of Nepal
}

\author{
Deepa Paudel $\left(D,{ }^{1}\right.$ Krishna Raj Tiwari, ${ }^{1}$ Nani Raut, ${ }^{2}$ Bishal K. Sitaula, ${ }^{3}$ Suman Bhattarai, \\ Yajna Prasad Timilsina, ${ }^{1}$ and Shivaraj Thapa ${ }^{4}$ \\ ${ }^{1}$ Institute of Forestry, Tribhuvan University, Pokhara, Nepal \\ ${ }^{2}$ Department of Environmental Science and Engineering, School of Science, Kathmandu University, Dhulikhel, Nepal \\ ${ }^{3}$ Department of International Environment and Development Studies, Norwegian University of Life Sciences, As, Norway \\ ${ }^{4}$ Environmental Resource Management -ERM, Kathmandu, Nepal
}

Correspondence should be addressed to Deepa Paudel; skt.deepa@gmail.com

Received 21 May 2021; Revised 8 June 2021; Accepted 13 June 2021; Published 24 June 2021

Academic Editor: Shah Fahad

Copyright $\odot 2021$ Deepa Paudel et al. This is an open access article distributed under the Creative Commons Attribution License, which permits unrestricted use, distribution, and reproduction in any medium, provided the original work is properly cited.

Farmers are predominantly adopting two forms of agroforestry, traditional and improved practices, in the midhills of Nepal, but their efficacy on a comparative basis is poorly assessed, so farmers often confuse whether to continue the traditional practice or embrace the improved practice. We carried out a study in six villages of three districts, interviewed 210 farmers adopting each practice, organized six focus group discussions, and interacted with 24 key informants to compare agroforestry practices from income generation and forest conservation perspectives. An individual household adopting the improved practice annually generated 841.60 US\$, which was more than two folds of the traditional practitioner. Similarly, the improved practitioner annually fulfilled $84 \%$ demand for forest products from the adopted agroforestry practice, whereas the traditional practitioner only fulfilled about $50 \%$. The fodder, fuelwood, and timber productions were found to be significantly higher in the improved practice, whereas leaf litter production was found to be almost similar. The improved practitioners seemed to be self-sustained in forest products, where the traditional practitioners only satisfied half of their requirements from the agroforestry practice. The study concludes that the improved agroforestry practice is more beneficial compared to the traditional practice. Therefore, we suggest the traditional practitioners to modify their ongoing practice to enhance the contribution of agroforestry practice at the local level.

\section{Introduction}

The practice of growing trees on agricultural land, popularly known as agroforestry practice, ensures goods and services to farmers [1-4] so the practice is considered as prominent basis to rural livelihood [5-7]. Agroforestry is a land use system where agriculture and forestry disciplines are combined to produce multiple products (food, timber, fodder, fuelwood, leaf litter, etc.) in a given space and time [8-11]. Alarming rate of deforestation and easy access to market because of infrastructure development have intensified agroforestry practices in rural areas [12]. Selection of better agroforestry practices is crucial for optimizing benefits in a same land management unit [13].

Agroforestry is widely considered as practice of economic opportunity to farmers for satisfying subsistence in developing countries like Nepal [14-17]. Several scholars have highlighted that agroforestry practices have importantly contributed to local livelihood in many countries such as Bangladesh, Sri Lanka, the Philippines, Kenya, and Nepal [2, 18-21]. However, they often failed to highlight and recommend better practice to enhance contribution of 
agroforestry practices. In Nepal, rural households are depending on surrounding natural forest for fulfilling their demand of fodder, fuelwood, leaf litter, and timber which can be made available in own farmland through agroforestry practices [18]. Likewise, the government also seems positive in expanding agroforestry in the country. The fourteenth plan (2013/14-2015/16) has encouraged farmers, communities, and private sectors to grow valuable plant species in their own land by simplifying procedure of harvesting, commercialization, and marketing [22]. Though efforts are being made for the promotion of agroforestry practices, there is still a huge gap in identifying better agroforestry practice. Nevertheless, some studies on agroforestry have been conducted in Nepal such as contribution on households' economy [23], livelihood enhancement and food security [24], and satisfying households' requirements $[25,26]$. The studies conducted so far seemed insufficient to provide substantial backup to appraise better agroforestry practices. Therefore, the study on effectiveness of different agroforestry practices along with contribution of tree species on livelihood seems scanty till date.

Farmers have been knowingly or unknowingly adopting agroforestry practice and fulfilling requirements of forest products and generating household income [27-29]. Farmers are exercising different types of agroforestry practices in Nepal [26]. Currently, some farmers are doing modification in ancient agroforestry practice for commercial benefits along with satisfying household requirements of forest-based products, so two forms of agroforestry exist in Nepal, which are broadly classified as the traditional practice and the improved practice [2]. The traditional practice indicates growing of naturally regenerated trees on farmland with less intensive use of agriculture inputs, whereas the improved practice includes cultivation of high yielding varieties of trees with high use of agriculture inputs. Despite introducing of the improved agroforestry practice in the village, many farmers are still in dilemma whether to continue the traditional practice or embrace the improved practice due to inadequate information about the significance of adopted practices. Hence, the comparative study became crucial to assess efficacy of both practices especially based on three major outputs: (a) supply of the forest products, (b) generation of the household income, and (c) contribution to forest conservations.

This study was conceptualized to make comparative assessment to quantify contribution of tree products to household need of the farmers in the midhills of Nepal. The study focused on the following: (1) assessing contribution of trees grown on farmland to fulfill demand of forest products and (2) comparing performances of existing agroforestry practices based on their production. The study findings will support in developing strategies to encourage farmers in making informed decisions for adopting different nature of agroforestry practices.

\section{Materials and Methods}

2.1. Study Area. We conducted preliminary survey in ten midhills districts of Nepal to record existing practices and types of agroforestry adopted in the locality. We further consulted experts, forest officials, academician, and local farmers to identify study sites. We followed criteria as described by [2] for distinguishing existing agroforestry practices as the traditional and the improved practices. In the traditional practice, farmers promote naturally regenerated woody perennials in alley of farmland in order to fulfill subsistence needs of forest products, whereas in the improved practice, farmer grows woody perennial, fruits, and cash crops along with agricultural crop for commercial purposes in addition to fulfilling subsistence needs. Similarly, the traditional practitioner continues their old-style farming practice, but the improved practitioner does modification in their old farming style and adopts new farming techniques such as introducing new plants and planting trees within terrace. Guided by this, we selected three villages, namely, Nirmal Pokhari, Chhaang, and Karen Danda from the three respective districts, Kaski, Tanahu, and Syangja, of Nepal (Figure 1). In the study sites, farmers were practicing both the improved and the traditional agroforestry practices. These districts are situated in subtropical climatic zone, nationally known as midhills in Nepal [30].

2.2. Methods. Fodder, fuelwood, leaf litter, and timber are major consumptive materials for household available from the agroforestry practices [26]. In addition, farmers are generating income from selling the cash crops such as vegetables, fruits, grass, and livestock products, such as milk and live animals. We confined our study on these products and prepared semistructured questionnaire for farmer interview. We selected 12 farmers (six from each category) to pretest and finalize the questionnaire. Afterwards, six focus group discussions were organized with farmer groups/cooperatives to map farmer practicing each category of the agroforestry practices in the studied villages. A sampling frame was then prepared for selection of the farmer. Afterwards, 70 farmers from each study site were selected randomly from each agroforestry practice. Hence, a total of 420 (210 traditional and 210 improved) farmers were interviewed from all agroforestry practices. In addition, six focus group discussions were organized in each type of practitioner (improved and traditional) to validate the information collected from household survey. Moreover, we also interviewed 24 key informants, government officers, leader of different farmers groups, and agricultural cooperation at the local level, to understand agroforestry practices and verify price of the products, including differences between two practices.

Price of product differs place to place based on availability and consumption rate. Farmers followed "bhari" (equal to $35 \mathrm{~kg}$ ) as local unit for measuring fodder, fuelwood, and leaf litter. Therefore, we asked individual households about the local price of available products. Interestingly, we found that villagers have similar response on price of products. Moreover, price of products obtained from the individual household interviews was further validated from focus group discussion and fixed as follows: fodder NRs 55.00 per $35 \mathrm{~kg}$, fuelwood NRs 70.00 per $35 \mathrm{~kg}$, leaf litter NRs 35.00 per $35 \mathrm{~kg}$, and timber NRs 7063.00 per $\mathrm{m}^{3}$, where 1 US\$ equals to 116.65 Nepalese Currency Rupees-NRs (Nepal Rastra Bank, Nepal, February 2, 2021). 
2.3. Data Analysis. Several studies have highlighted contributions to farmers' household and forest conservation, but they often failed to compare different practices adopted. Therefore, this study was conceptualized to access efficacy of two types of agroforestry practices adopted in the study sites in order to suggest stakeholders for promoting better practice. We compared existing agroforestry practices in monetary form on the basis of available forest (tree) products from adopted practices. We hypothesized that better practice generates more income, forest-based products, and contribution to forest conservation. Thus, all data (fodder, fuel wood, leaf litter, and timber) were categorized by agroforestry practices, that is, traditional and improved practices. Simple descriptive statistics such as average and percentage were computed with respect to agroforestry practices. In addition, we transferred the data into normality $\log ($ value +10$)$ for supply of forest products, fodder, fuelwood, leaf litter, and timber. Two-independent-sample $t$-test was carried out to compare tree-based products available from two agroforestry practices.

\section{Results}

Though agroforestry practice provides multiple goods and services, farmers basically adopt agroforestry practice to fulfill household demand of forest-based products. So, this study focused on household income and supply of forest products from agroforestry practice.

3.1. Supply of Forest Products. The improved practice was found to be more beneficial than the traditional practice based on the supply of products. The improved practitioners annually needed fodder, fuelwood, leaf litter, and timber in the quantity of $9030 \mathrm{~kg}, 2100 \mathrm{~kg}, 1820 \mathrm{~kg}$, and $0.170 \mathrm{~m}^{3}$, respectively, in average (Table 1). Out of this demand, the improved practice supplied $90 \%, 92 \%, 67 \%$, and $25 \%$ of fodder, fuelwood, leaf litter, and timber, respectively. Similarly, the traditional farmer annually required $8435 \mathrm{~kg}, 1575 \mathrm{~kg}, 1330 \mathrm{~kg}$, and $0.113 \mathrm{~m}^{3}$ of fodder, fuelwood, leaf litter, and timber, respectively, whereas the traditional practice supplied $53 \%, 51 \%, 37 \%$, and $25 \%$ of fodder, fuelwood, leaf litter, and timber, respectively. Hence, the improved practitioners not only required but also collected more forest products from agroforestry practices adopted.

Production of forest products needed for household was one of the major objectives of adopting agroforestry practice. Fodder, fuelwood, leaf litter, and timber were major forest products; those could be made available through agroforestry practice. So, supply of these products could be a basis to compare the efficacy of adopted agroforestry practices. Therefore, parametric two-independent-sample $t$-test was carried out to find out variations in supply of forest products available from two agroforestry practices. Supply of each product available from the improved practice was found to be higher than that from the traditional practice. Significant difference was observed between the two practices in case of producing fodder $(p \leq 0.003)$, fuelwood $(p \leq 0.001)$, and timber $(p \leq 0.016)$, whereas supply of leaf litter was found to be nonsignificant (ns) $(p \leq 0.709)$ (Table 2).
3.2. Contribution to Household Income. Farmers were producing cash crop, livestock, and forest products as major benefits from agroforestry practice. The improved practitioner generated more income compared to the traditional practitioner. Income from the improved practice was 841.60 US\$ per household per year (US\$/hh/yr), whereas only $326.40 \mathrm{US} \$ \mathrm{hh} / \mathrm{yr}$ was found in case of the traditional practice (Figure 2). Cash crops, such as fruits and coffee, hold major part of income and are followed by livestock and forest products in the improved practice. Similarly, livestock was found to be the main source of income followed by forest products and cash crops in the traditional practice.

Out of the total income (Figure 2), forest product covered 18\% (155 US\$) and 24\% (79.6 US\$) in the improved practice and the traditional practice, respectively. Both practices appeared supportive in fulfilling major part of forest products required for the households. Nevertheless, their quantifications differed from each other. In comparison, the improved practice was found to be more supportive to farmers than the traditional practice (Table 3). Supply of forest products was calculated in terms of monetary value based on the local prices (further converted into US\$) and available volume. The improved practice produced forest products worth 155.00 US\$, whereas the traditional practice produced products worth 79.60 US\$. However, the total demands of the improved and the traditional practitioners were 184.00 US\$ and 159.00 US\$, respectively. Specifically, the improved practice contributed fodder, fuelwood, leaf litter, and timber worth 108.90 US\$, 33.00 US\$, 10.50 US\$, and 2.60 US\$, respectively, to individual household annually. Similarly, individual household adopting the traditional practice annually gained fodder, fuelwood, leaf litter, and timber worth 59.90 US\$, 13.80 US\$, 4.20 US\$, and, 1.70 US\$, respectively.

The farmer adopting the improved practice saved $84 \%$ expenses that have to be paid for forest products for fulfilling their household demand, whereas the traditional farmer saved only $50 \%$ of expenses from the agroforestry practice. Out of total saving, fodders, fuelwood, leaf litter, and timber covered $70 \%, 21 \%, 7 \%$, and $2 \%$, respectively, in case of the improved practitioner, whereas the traditional farmer only saved $75 \%, 17 \%, 7 \%$, and $2 \%$, respectively (Figure 3 ). The results showed that the improved practice was more beneficial than the traditional practice, where fodder was the main benefitted forest product available from agroforestry practice.

3.3. Contribution of Agroforestry Practice on Forest Conservation. As surrounding forests were the ultimate sources for local people to fulfill their household requirements of forest products, farmers of the study areas were also depending on adjoining forest for fulfilling the deficit forest products. We here calculated the deficit products and agroforestry contribution to reduce pressure on adjoining forest (Tables 1 and 4). Out of the total demand, the improved practitioners fetched only $10 \%, 8 \%, 33 \%$, and $75 \%$ of fodder, fuelwood, leaf litter, and timber, respectively, from surrounding forests, whereas the traditional farmers derived 


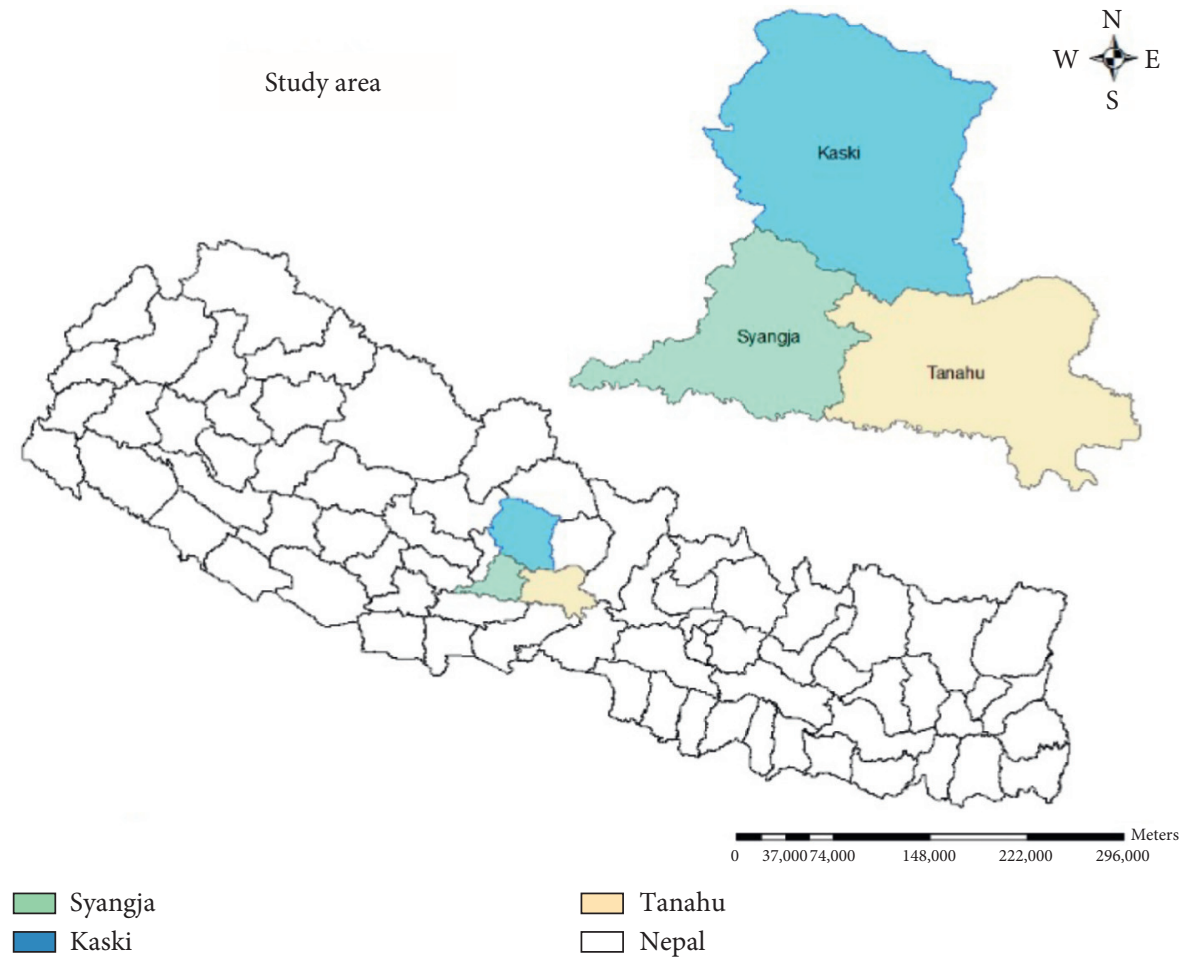

FIgURE 1: Study area showing three districts of midhills of Nepal.

TABle 1: Demand of the local household and contribution from agroforestry practice.

\begin{tabular}{|c|c|c|c|c|c|c|c|c|}
\hline \multirow{2}{*}{ AF practices } & \multicolumn{2}{|c|}{ Fodder* } & \multicolumn{2}{|c|}{ Fuelwood* } & \multicolumn{2}{|c|}{ Leaf litter* } & \multicolumn{2}{|c|}{ Timber** } \\
\hline & Demand & Supply & Demand & Supply & Demand & Supply & Demand & Supply \\
\hline Improved & 9030 & $8085(90)$ & 2100 & $1925(92)$ & 1820 & $1225(67)$ & 0.170 & $0.042(25)$ \\
\hline Traditional & 8435 & $4445(53)$ & 1575 & $805(51)$ & 1330 & $490(37)$ & 0.113 & $0.028(25)$ \\
\hline
\end{tabular}

${ }^{*} \mathrm{~kg} / \mathrm{hh} / \mathrm{yr} ;{ }^{* *} \mathrm{~m}^{3} / \mathrm{hh} / \mathrm{yr}$. The numbers in parentheses indicate the percentage of demand.

TABLE 2: Supply of forest products from different agroforestry practices.

\begin{tabular}{|c|c|c|c|c|c|}
\hline Forest product & Agroforestry practice & Mean \pm SE & Min & Max & Sig \\
\hline \multirow{2}{*}{ Fodder (bhari at $35 \mathrm{~kg}$ ) } & Improved & $5.3602 \pm 0.0377$ & 2.6 & 6.4 & \multirow{2}{*}{$0.003^{*}$} \\
\hline & Traditional & $4.6806 \pm 0.0556$ & 2.3 & 6.1 & \\
\hline \multirow{2}{*}{ Fuelwood (bhari at $35 \mathrm{~kg}$ ) } & Improved & $4.058 \pm 0.03357$ & 2.3 & 5.3 & \multirow{2}{*}{$0.001^{*}$} \\
\hline & Traditional & $3.3063 \pm 0.0417$ & 2.3 & 5.1 & \\
\hline \multirow{2}{*}{ Leaf litter (bhari at $35 \mathrm{~kg}$ ) } & Improved & $3.823 \pm 0.05418$ & 2.3 & 5.6 & \multirow{2}{*}{0.709} \\
\hline & Traditional & $3.5105 \pm 0.0563$ & 2.3 & 5.8 & \\
\hline \multirow{2}{*}{ Timber (cubic feet at $0.02831 \mathrm{~m}^{3}$ ) } & Improved & $2.3653 \pm 0.0138$ & 2.3 & 3.4 & \multirow{2}{*}{$0.016^{*}$} \\
\hline & Traditional & $2.3423 \pm 0.0118$ & 2.3 & 5.8 & \\
\hline
\end{tabular}

*Significant at $p<0.05$. Computation is based on transferred data $(\operatorname{Ln}($ value $)+10)$.

$47 \%, 49 \%, 63 \%$, and $75 \%$ of fodder, fuelwood, leaf litter, and timber, respectively, from adjoining forests to overcome the shortage. The individual improved practitioner annually fetched $945 \mathrm{~kg}, 175 \mathrm{~kg}, 595 \mathrm{~kg}$, and $0.128 \mathrm{~m}^{3}$ of fodder, fuelwood, leaf litter, and timber, respectively, from the natural forest, while the individual traditional practitioner annually visited forest to collect $3990 \mathrm{~kg}, 770 \mathrm{~kg}, 1512 \mathrm{~kg}$, and
$0.085 \mathrm{~m}^{3}$ of fodder, fuelwood, leaf litter, and timber, respectively. Despite consuming more forest products, the improved farmers fulfilled most of their demand of forest products from agroforestry compared to the traditional practices. Therefore, the contribution of the improved practice to forest conservation seemed to be more than that of the traditional practice. 


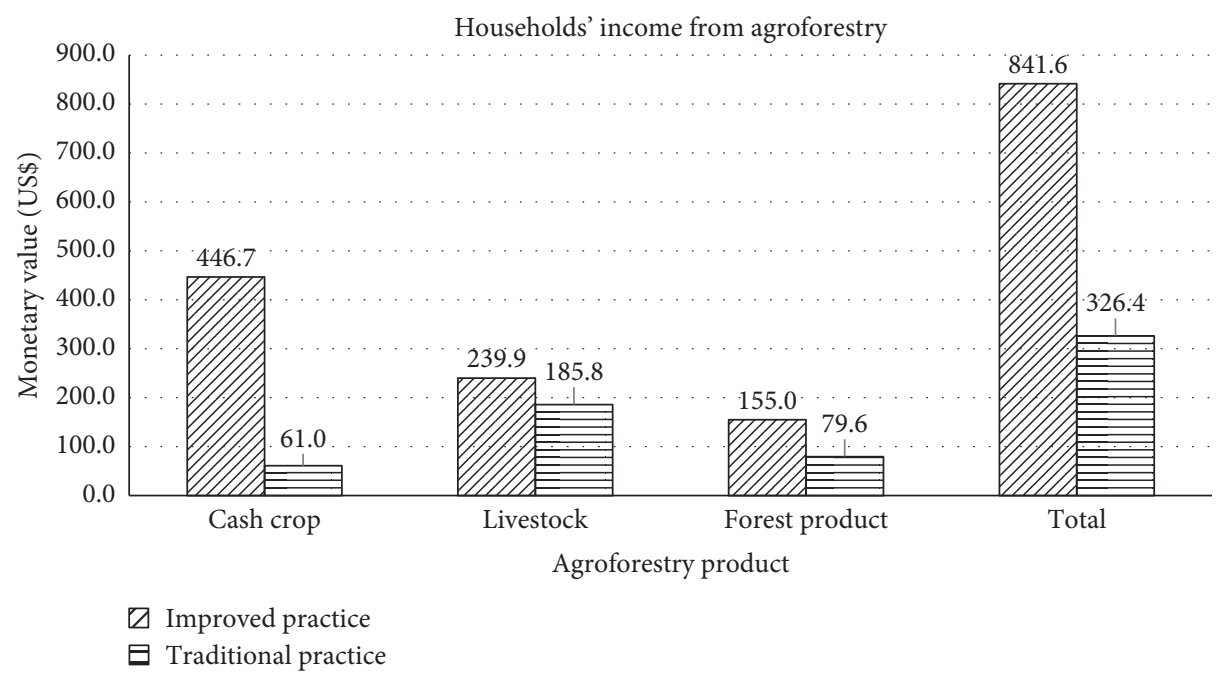

Figure 2: Product-based monetary contribution.

TABLE 3: Monetary valuation of available forest products.

\begin{tabular}{|c|c|c|c|c|c|c|c|c|c|}
\hline \multirow{2}{*}{ AF practices } & \multicolumn{2}{|c|}{ Fodder } & \multicolumn{2}{|c|}{ Fuelwood } & \multicolumn{2}{|c|}{ Leaf litter } & \multicolumn{2}{|c|}{ Timber } & \multirow{2}{*}{ Total worth ${ }^{4}$} \\
\hline & Supply* & Worth $^{\Psi}$ & Supply* & Worth $^{\Psi}$ & Supply* & Worth $^{\Psi}$ & Supply** & Worth ${ }^{\Psi}$ & \\
\hline Improved & 8085 & 108.9 & 1925 & 33 & 1225 & 10.5 & 0.042 & 2.6 & 155 \\
\hline Traditional & 4445 & 59.9 & 805 & 13.8 & 490 & 4.2 & 0.028 & 1.7 & 79.6 \\
\hline Total & \multicolumn{4}{|c|}{ Improved practice $=155.00 \mathrm{US} \$ / \mathrm{hh} / \mathrm{yr}$} & \multicolumn{4}{|c|}{ Traditional practice $=79.60 \mathrm{US} \$ / \mathrm{hh} / \mathrm{yr}$} & \\
\hline
\end{tabular}

${ }^{*} \mathrm{~kg} / \mathrm{hh} / \mathrm{yr} ;{ }^{* *} \mathrm{~m}^{3} / \mathrm{hh} / \mathrm{yr} ;{ }^{\Psi}(\mathrm{US} \$ / \mathrm{hh} / \mathrm{yr}) ;$ exchange rate (1.00 US $\$=116.65$ Nepalese currency-NRs).

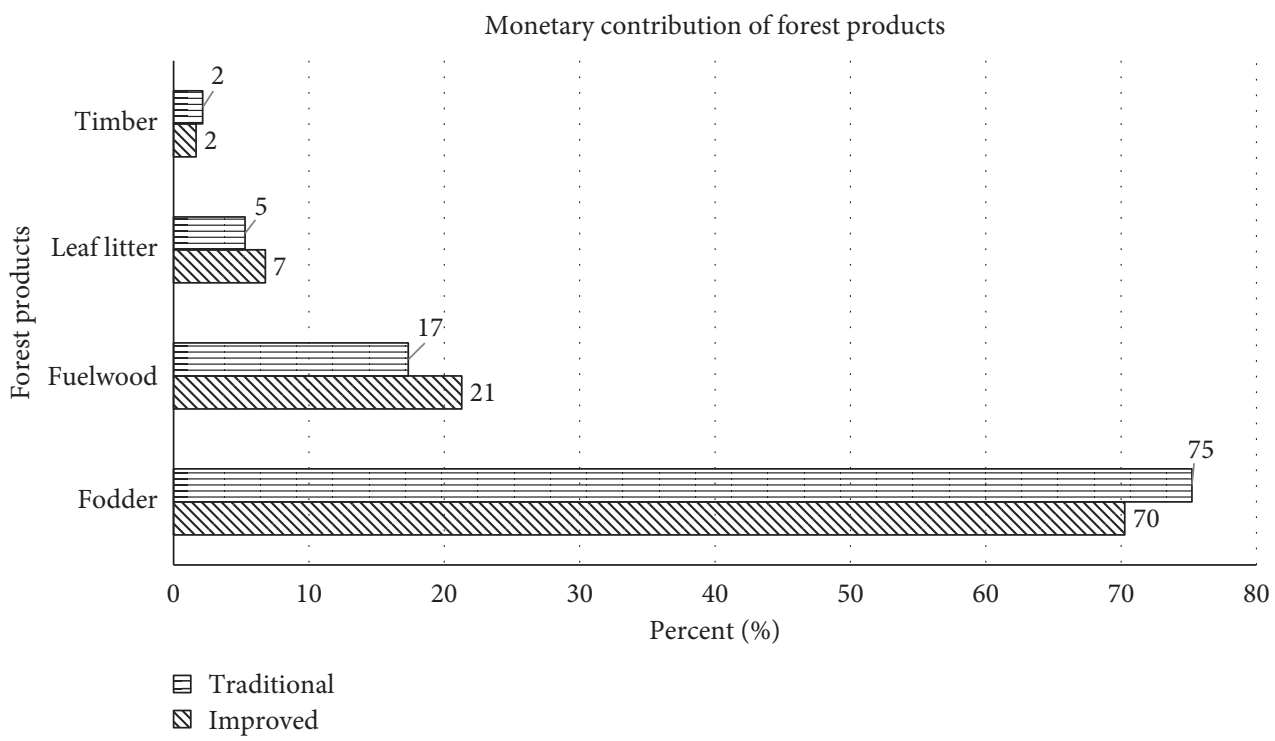

FIgURE 3: Monetary contribution of forest-based products to household income.

TABLE 4: Deficit products from the agroforestry system at the local level.

\begin{tabular}{lcccc}
\hline Agroforestry system & Fodder* & Fuelwood $^{*}$ & Litter* $^{*}$ & Timber** $^{*}$ \\
\hline Improved & $945(10)$ & $175(8)$ & $595(33)$ & $0.128(75)$ \\
Traditional & $3990(47)$ & $770(49)$ & $1512(63)$ & $0.085(75)$ \\
\hline
\end{tabular}

${ }^{*} \mathrm{~kg} / \mathrm{hh} / \mathrm{yr} ;{ }^{* *} \mathrm{~m}^{3} / \mathrm{hh} / \mathrm{yr}$. The numbers in parentheses indicate the deficit percentage of demand. 


\section{Discussion}

4.1. Availability of Forest Products. Both types of agroforestry practices have been supporting farmers' household and forest conservation. Our study reveals that farmers were collecting different forest products, such as timber, firewood, fodder, and litter from the adopted practices. Reference [31] found that farmers fulfilled about $50 \%$ of fuelwood, $66 \%$ of small timber, $70-80 \%$ of raw materials for plywood, $60 \%$ of raw material for paper pulp, and $9-11 \%$ of fodder from agroforestry. Our result looked similar to [31] in case of fuelwood, whereas it differed in fodder production; it might be due to farmers' objective of adopting practice. Our findings completely differed from the finding of [26], which reported that agroforestry practice in Chure range of central Nepal only fulfilled $50 \%, 25 \%$, and $50 \%$ of household demand of fodder, fuelwood, and leaf litter, respectively. In our study areas, the improved farmers were close to be selfsustained and the traditional farmers derived about $50 \%$ of forest products except leaf litter (37\%) from agroforestry practice adopted. Household demand, landholding size, extent of livestock rearing, and type of agroforestry practices might be the reasons for these differences.

Limited access to other resources has encouraged poor farmers to adopt agroforestry practice as wise use of their limited land resources to fulfill their household requirements [32]. Though agroforestry practice is contributing to household, the existing production is not enough to satisfy the demand of farmers [26], which resonated with our findings. The farmers used their own farmland production first and then only visited surrounding natural forest for fulfilling deficit products. The cases of Jalalabad, Bagrot, and Rajshahi were also similar to ours, where farmers depended highly on agroforestry practice and negligibly on surrounding forest for fuelwood and timber [33-35]. Both the traditional and the improved practitioners were depending on natural forest; however, the dependency of the traditional practitioners was more due to less availability of forest products in the farmlands. Strengthening current practice [26] with embracing modern technologies and promotion of new species can be a better option to increase the production.

The farmers who are still adopting the traditional practice are unable to gain benefits as compared to the improved practitioners, so they need to improve their current practice to be self-sustained in forest-based products. Compared to the past, multiple sources of energy are available at the local level, i.e., biogas, electricity, and petroleum gas, so local dependency on adjoining forest for fuelwood was not a major issue in the study area. Similarly, naturally grown Schima wallichii was a main tree species in farmland, which was mostly used for timber, agricultural tools, and cowshed and rarely used in building construction. The farmers preferred strong and durable species, Shorea robusta, for construction purpose; thus contribution percentage of agroforestry to timber production seemed to be less in our study site compared to [31]. The farmer hardly grew timber species besides caring about naturally regenerated species. So, there was a maximum chance of increasing farmers' dependency on natural forest for the timber. Similarly, because of ease access to the market and high market value, the farmers were attracted to livestock rearing like goat farming for meat and buffalo rearing for dairy products. The improved practitioners were growing native as well as other fodder species, while the traditional practitioners were still limiting themselves to locally available species. Thus, the farmers needed to be encouraged to introduce high-quality fodder species.

The improved agroforestry practice looked better for conserving surrounding natural forest compared to the traditional practice. Modification of current agroforestry practice into the improved practice could have more potentialities to increase forest products within private land and conserve forest resources.

4.2. Monetary Contribution of the Agroforestry System to Farmer's Household. Agroforestry is a viable option in raising income, enhancing local livelihoods, and sustaining environmental benefits [34]. Growing trees in farmland pledges regular economic profit and societal development of farmers $[36,37]$. Saving expenses through utilizing products available from farmland is also considered as households' income while valuing agroforestry practice. The farmers who are practicing agroforestry in Nepal are generating multiple products required for household and saving household budget. Therefore, agroforestry is widely taken as the source of income at local households' level. People are growing trees in their farmland and generating multiple products, fodder, fuelwood, leaf litter, and timber. Tree products support the farmers widely, but they are often ignored in valuing monetary term, so farmers' attraction seems low. Similar to our finding, the farmers of other areas, Jalalabad, Bagrot, etc., are also generating income from tree-based products [33-35]. However, quantity and income seem to be different due to landholding size and type of adopted practices. The farmers in Jalalabad generated income worth 114.85 US\$ (10\%) from fuelwood and worth 28.9 US\$ (3\%) from timber production and the farmers in Bagrot made profits of 13.81 US\$ (2\%) from fuelwood and 2.85 US\$ $(0.5 \%)$ from timber [33]. Specifically, the amounts reported by [33] were more than those reported in our study area.

4.3. Contribution of Agroforestry Practice on Forest Conservation. The aim of agroforestry practice is to fulfill farmers' need of forest products along with agricultural and cash crops, which ultimately reduce human pressure on surrounding natural forest [24]. In our case also, contribution of both practices seems supportive in conserving forest situated nearby local village. The farmers are utilizing their farmland for forest-based products required for their household, but still they depend on surrounding forest to fulfill the deficit demand $[6,25]$. The improved practitioners are fulfilling their maximum portion of demand $(90 \%$ fodder, $92 \%$ fuelwood, and $67 \%$ leaf litter) from their farmland. This conquers need of modifying the traditional practice into the improved practice to increase production in farmland and enhance contribution on forest conservation [38]. Currently, both practices accomplish only one-fourth of timber demand and farmers have to depend more on surrounding natural forest for satisfying timber demand. The 
farmers are focusing on naturally grown and native species rather than adopting multipurpose and fast-growing species available in the locality. The traditional practice is only fulling about half portion of demand where plant density seems to be less than that in the improved practice, so planting more trees along with retaining and caring about naturally growing plants would have more potentiality in enhancing supply and be self-sustained in forest-based products. The cases of Jalalabad and Bagrot are also similar to ours where the farmers depend negligibly on surrounding forest for fuelwood and timber [33] because of agroforestry practices. Similarly, [34, 35] have also comparable evidence from Rajshahi that adoption of agroforestry practice is a reason for reducing. Encouraging farmers to adopt multipurpose and fast-growing species could increase production, which eventually narrow down the gap of supply and demand of forest products [24]. Our findings also matched with Rahman et al. [39], who have reported agroforestry practice as livelihood solution and source of economic return to poor farmers, source of forest products, and the strategy of forest conservation. Based on our findings, we advise for the improvement of current agroforestry practice in order to make farmers self-sustained in forest products required for meeting households' demand through wise utilization of available land resources.

\section{Conclusion}

In Nepal, the farmers are practicing two different types of agroforestry practices. The improved farming generated more benefits to the farmers. The improved farmer and the traditional farmer individually generated average annual incomes of 841.60 US\$ and 326.40 US\$, respectively. Likewise, individual household adopting the improved practice was saving 155.00 US\$ ( $84 \%$ of total demand), whereas the traditional dweller was saving 79.60 US\$ (about 50\% of total demand) per year from tree species grown in own farmland. However, forest products produced from farmland were not sufficient to satisfy existing household's demand, where the farmers still needed to depend more on forest for timber compared to other products. Nevertheless, the improved practitioner was found to be closer to be self-sustained (up to 92\%) than the traditional practice. Though agroforestry practice has been supported in forest conservation, still there was possibility to reduce pressure on adjoining forest if the traditional practice could be modified into the improved practice. Improvement of agroforestry has potential for contributing to household income and forest conservation, so the study suggests farmers and concerned stakeholders modifying the traditional practice and strengthening the improved practice. Similarly, this study also recommends further study to explore the determinants that affect the farmer to adopt specific practice of agroforestry at the local level.

\section{Data Availability}

This paper is a part of a study. The authors are preparing other papers to see other dimensions of agroforestry practices, so the data are not shared here. Scholars interested in the data can contact the corresponding author.

\section{Disclosure}

The funders had no role in the design of the study; in the collection, analyses, or interpretation of the data; in the writing of the manuscript; or in the decision to publish the results.

\section{Conflicts of Interest}

The authors declare no conflicts of interest.

\section{Acknowledgments}

The authors are thankful to all the farmers involved in the study period. They would like to thank Bijendra Basnyat, Bishnuhari Wagle, Prabin Poudel, Pawan Karki, Sistata Bagale, Sara Ranabhat, Ram Thapa, and Resham Karki for their support during fieldwork. NORHED SUNREMHimalaya Project for South Asia provided financial assistance to carry out the fieldwork and data collection of this study.

\section{References}

[1] S. Foli, J. Reed, J. Clendenning, G. Petrokofsky, C. Padoch, and T. Sunderland, "To what extent does the presence of forests and trees contribute to food production in humid and dry forest landscapes?: a systematic review protocol," Environmental Evidence, vol. 3, no. 1, pp. 15-18, 2014.

[2] D. Paudel, K. R. Tiwari, N. Raut, B. K. Sitaula, and P. Paudel, "Agroforestry practices in midhills of Nepal from gender perspective," Open Journal of Forestry, vol. 9, no. 4, pp. 323-340, 2019.

[3] J. Reed, J. van Vianen, S. Foli et al., "Trees for life: the ecosystem service contribution of trees to food production and livelihoods in the tropics," Forest Policy and Economics, vol. 84, pp. 62-71, 2017.

[4] W. D. Sunderlin, A. Angelsen, B. Belcher et al., "Livelihoods, forests, and conservation in developing countries: an overview," World Development, vol. 33, no. 9, pp. 1383-1402, 2005.

[5] S. M. Amatya and S. M. Newman, "Agroforestry in Nepal: research and practice," Agroforestry Systems, vol. 21, no. 3, pp. 215-222, 1993.

[6] S. M. Amatya, "Fodder trees and their lopping cycle in Nepal," 1990, https://www.cabdirect.org/cabdirect/abstract/ 19910655709.

[7] C. J. Garforth, Y. B. Malla, R. P. Neopane, and B. H. Pandit, "Socioeconomic factors and agro-forestry improvements in the hills of Nepal," Mountain Research and Development, vol. 19, no. 3, pp. 273-278, 1999.

[8] J. G. Bene, H. W. Beall, and A. Côté, Trees, Food and People: Land Management in the Tropics, IDRC, Ottawa, Canada, 1977.

[9] B. Jama, E. Elias, and K. Mogotsi, "Role of agroforestry in improving food security and natural resource management in the drylands: a regional overview," Journal of the Drylands, vol. 1, no. 2, pp. 206-211, 2006.

[10] S. Jose, "Agroforestry for ecosystem services and environmental benefits: an overview," Agroforestry Systems, vol. 76, no. 1, pp. 1-10, 2009.

[11] K. G. MacDicken and N. T. Vergara, Agroforestry: Classification and Management, John Wiley \& Sons, Hoboken, NJ, USA, 1990. 
[12] D. Alemagi, L. Duguma, P. A. Minang, F. Nkeumoe, M. Feudjio, and Z. Tchoundjeu, "Intensification of cocoa agroforestry systems as a REDD+ strategy in cameroon: hurdles, motivations, and challenges," International Journal of Agricultural Sustainability, vol. 13, no. 3, pp. 187-203, 2015.

[13] P. A. Huxley and H. Van Houten, Glossary for Agroforestry, International Centre for Research in Agroforestry, Nairobi, Kenya, 1997.

[14] K. Aryal, P. S. Thapa, and D. Lamichhane, "Revisiting agroforestry for building climate resilient communities: a case of package-based integrated agroforestry practices in Nepal," Emerging Science Journal, vol. 3, no. 5, pp. 303-311, 2019.

[15] R. Khanal, C. P. Pokhrel, and R. K. Yadav, "Some wild plants and their local use in midhill region of Nepal," Journal of Institute of Science and Technology, vol. 18, no. 2, pp. 93-97, 2013.

[16] G. Rasul and G. B. Thapa, "Financial and economic suitability of agroforestry as an alternative to shifting cultivation: the case of the Chittagong hill tracts, Bangladesh," Agricultural Systems, vol. 91, no. 1-2, pp. 29-50, 2006.

[17] S. J. Scherr, "Building opportunities for small-farm agroforestry to supply domestic wood markets in developing countries," Agroforestry Systems, vol. 61-62, no. 1-3, pp. 357-370, 2004.

[18] S. M. Amatya, E. Cedamon, and I. Nuberg, "Agroforestry systems and practices in Nepal. agroforestry systems and practices in Nepal," 2018, http://www.afu.edu.np/.

[19] N. Byron, "People's forestry: a novel perspective of forestry in Bangladesh'," Association of Development Agencies in Bangladesh News, vol. 11, pp. 31-37, 1984.

[20] A. J. Simons and R. R. B. Leakey, "Tree domestication in tropical agroforestry," In New Vistas in Agroforestry, pp. 167-181, Springer, Dordrecht, Netherlands, 2004.

[21] F. Place, R. Zomer, R. Kruska et al., "Development pathways in medium-high potential Kenya: A meso level analysis of agriculturalpatterns and determinants," in Proceedings of the Conference on Policies for Sustainable Land Management in the East African Highlands, Addis Ababa, Ethiopia, April 2002.

[22] National Planning Commission, The Fourteenth Plan (2013/ 14-2015/16), National Planning Commission, Government of Nepal, Kathmandu, Nepal, 2013.

[23] N. R. Pandit, D. Gautam, and S. Adhikari, "Role of agroforestry practices in changing rural livelihood economy: case study of Dhaibung VDc of Rasuwa district," The Initiation, vol. 5, pp. 32-42, 2013.

[24] E. D. Cedamon, I. Nuberg, R. Mulia, B. Lusiana, Y. R. Subedi, and K. K. Shrestha, "Contribution of integrated forest-farm system on household food security in the mid-hills of Nepal: assessment with EnLiFT model," Australian Forestry, vol. 82, no. s1, pp. 32-44, 2019.

[25] K. B. Mohan, R. T. Krishna, K. Gandhiv, G. Shrikrishna, T. Shankar, and B. Bandana, "Farmers dependency on forests for nutrients transfer to farmlands in mid-hills and high mountain regions in Nepal (case studies in Hemja, Kaski, Lete and Kunjo, Mustang district)," International Journal of Biodiversity and Conservation, vol. 6, no. 3, pp. 222-229, 2014.

[26] D. Khadka, A. Aryal, K. P. Bhatta, B. P. Dhakal, and H. Baral, "Agroforestry systems and their contribution to supplying forest products to communities in the chure range, central Nepal," Forests, vol. 12, no. 3, p. 358, 2021.

[27] D. Amare, M. Wondie, W. Mekuria, and D. Darr, "Agroforestry of smallholder farmers in Ethiopia: practices and benefits," Small-Scale Forestry, vol. 18, no. 1, pp. 39-56, 2019.

[28] Y. B. Malla, "Farmers' tree management strategies in a changing rural economy, and factors influencing decisions on tree growing in Nepal," International Tree Crops Journal, vol. 10, no. 3, pp. 247-266, 2000.

[29] D. Murniati, D. P. Garrity, and A. N. Gintings, "The contribution of agroforestry systems to reducing farmers' dependence on the resources of adjacent national parks: a case study from Sumatra, Indonesia," Agroforestry Systems, vol. 52, no. 3, pp. 171-183, 2001.

[30] CBS Nepal, "National population and housing census 2011," National Report, Government of Nepal National Planning Commission Secretariat Central Bureau of Statistics Kathmandu, Nepal, 2012, https://unstats.un.org/unsd/demographic/ sources/census/wphc/Nepal/Nepal-Census-2011-Voll.pdf.

[31] A. K. Handa, O. P. Toky, S. K. Dhyani, S. B. Chavan, and I. D. Toky, "Innovative agroforestry for livelihood security in India," World Agriculture, vol. 7, pp. 7-16, 2016.

[32] M. A. Siddiqui and N. A. Khan, "Floristic composition and socio-economic aspects of rural homestead forestry in Chittagong: a case study," Bangladesh Journal of Forest Science, vol. 28, no. 2, pp. 94-101, 1999.

[33] M. Essa, S. M. Nizami, S. N. Mirza, I. A. Khan, and M. Athar, "Contribution of agroforestry in farmers' livelihood and its impact on natural forest in northern areas of Pakistan," African Journal of Biotechnology, vol. 10, no. 69, pp. 1552915537, 2011.

[34] G. M. Rahman and M. J. Alam, "Composotion and benefit of cropland agroforestry practices practiced in Rajshahi district," Journal of Agroforestry and Environment, vol. 1, pp. 149-153, 2007.

[35] P. Tiwari, R. Kumar, L. Thakur, A. Salve, and Y. Parmar, "Agroforestry for sustainable rural livelihood: a review," International Journal of Pure \& Applied Bioscience, vol. 5, no. 1, pp. 299-309, 2017.

[36] M. Chakraborty, M. Z. Haider, and M. M. Rahaman, "Socioeconomic impact of cropland agroforestry: evidence from Jessore district of Bangladesh," International Journal of Research in Agriculture and Forestry, vol. 2, no. 1, pp. 11-20, 2015.

[37] S. A. Rahman, T. Sunderland, M. Kshatriya, J. M. Roshetko, T. Pagella, and J. R. Healey, "Towards productive landscapes: trade-offs in tree-cover and income across a matrix of smallholder agricultural land-use systems," Land Use Policy, vol. 58, pp. 152-164, 2016.

[38] S. Baral, R. Malla, S. Khanal, and R. Shakya, "Trees on farms: diversity, carbon pool and contribution to rural livelihoods in Kanchanpur district of Nepal," Banko Janakari, vol. 23, no. 1, pp. 3-11, 2013.

[39] S. A. Rahman, F. D. Paras, S. R. Khan et al., "Initiatives of tropical agroforestry to sustainable agriculture: a case study of Capasia village, northern Bangladesh," Journal of Horticulture and Forestry, vol. 3, no. 4, pp. 115-121, 2011. 